\title{
Lampião, Lages, Lombroso: the autopsy of the bandit king of the Brazilian backlands
}

Lampião, Lages, Lombroso: a autópsia do Rei do Cangaço

Charles André1,2, Laura Minc Baumfeld André3

\begin{abstract}
Lampião, the most infamous Brazilian brigand leader, was killed and decapitated during an ambush in 1938. The Alagoas police coroner, Dr. José Lages Filho, performed an autopsy of his head. Strongly biased toward the anthropologic ideas of the famous Italian psychiatrist and criminalist Cesare Lombroso, the examination found only a few of the so-called criminal inborn traits. The Lombrosian doctrine and a number of related theories strongly influenced medical and political reasoning in the first half of the $20^{\text {th }}$ century. Modern genetic and neuroscientific studies are still looking for the potential biological roots of misbehavior and criminality.
\end{abstract}

Keywords: Autopsy; criminal behavior; Forensic Medicine; Forensic Anthropology; History; 20th century.

\section{RESUMO}

Lampião foi o líder cangaceiro mais famoso do Brasil. Foi morto e decapitado após emboscada em 1938. O Dr. José Lages Filho, perito médico-legal da polícia de Alagoas, realizou a autópsia parcial, restrita à cabeça. 0 exame focalizou essencialmente a busca de traços físicos característicos do chamado criminoso nato, de acordo com a teoria antropológica criminal desenvolvida pelo psiquiatra italiano Cesare Lombroso. A doutrina de Lombroso e outras com ela relacionadas influenciaram fortemente o raciocínio médico e político na primeira metade do século 20. Seus ecos são ainda hoje perceptíveis em estudos genéticos e neurocientíficos contemporâneos, que seguem procurando as raízes biológicas dos desvios comportamentais e da criminalidade.

Palavras-chave: Autópsia; comportamento criminoso; Medicina Legal; Antropologia Forense; História; Século XX.

\author{
"Nunca mais há de acendê \\ O tal Lampião falado. \\ Na capitá do Estado \\ Sua cabeça se vê \\ Para o governo conhecê \\ Sua terrive feição \\ E dizê: este é o dragão \\ Forte, crué e valente. \\ Porém mandei minha gente \\ E apagaro o Lampião". \\ Manuel Neném
}

Virgulino Ferreira da Silva (1898-1938) - best known as Lampião - was the most notorious leader of a form of banditry known in Brazil as cangaço, which was endemic in the north-east hinterlands in the first half of the $20^{\text {th }}$ century.
His outlaw group ravaged villages in the 1920s and 1930s. Regional and central governments made many attempts to decimate his troops, and finally succeeded in beheading him at dawn on July 28, 1938 - in Angicos, Sergipe. The ambush resulted in the death of 11 brigands (including two women) and one soldier. More than 20 other bandits escaped $^{1}$. The nickname Lampião, which in English means "lantern" or "oil lamp", was acquired because he could fire a lever-action rifle so fast that at night it looked as though he was holding a lamp ${ }^{1}$.

Lampião, his life mate Maria Bonita (Maria Gomes de Oliveira), and all of the others who were caught were decapitated (three of them while still alive) and their heads displayed in a number of villages (Figure 1) during their transport to Maceió (State of Alagoas), where a limited autopsy was performed.

${ }^{1}$ Universidade Federal do Rio de Janeiro, Faculdade de Medicina, Departamento de Neurologia, Rio de Janeiro RJ, Brasil;

${ }^{2}$ Sinapse Neurologia e Reabilitação, Rio de Janeiro RJ, Brasil;

${ }^{3}$ Promotor do Ministério Público do Estado do Rio de Janeiro, Rio de Janeiro RJ, Brasil.

Charles André (iD) https://orcid.org/0000-0001-8081-5741

Correspondence: Charles André; Rua Visconde de Pirajá, 414/ sala 821; 22410-002 Rio de Janeiro RJ, Brasil; E-mail: dr.charles.andre@gmail.com

Conflict of interest: There is no conflict of interest to declare.

Received 21 May 2018; Received in final form 18 July 2018; Accepted 16 August 2018. 
We searched for the original autopsy report, for documents and relatives of the doctor responsible for the autopsy. The present text reviews these results and discusses the influence of Anthropological Criminology at the time.

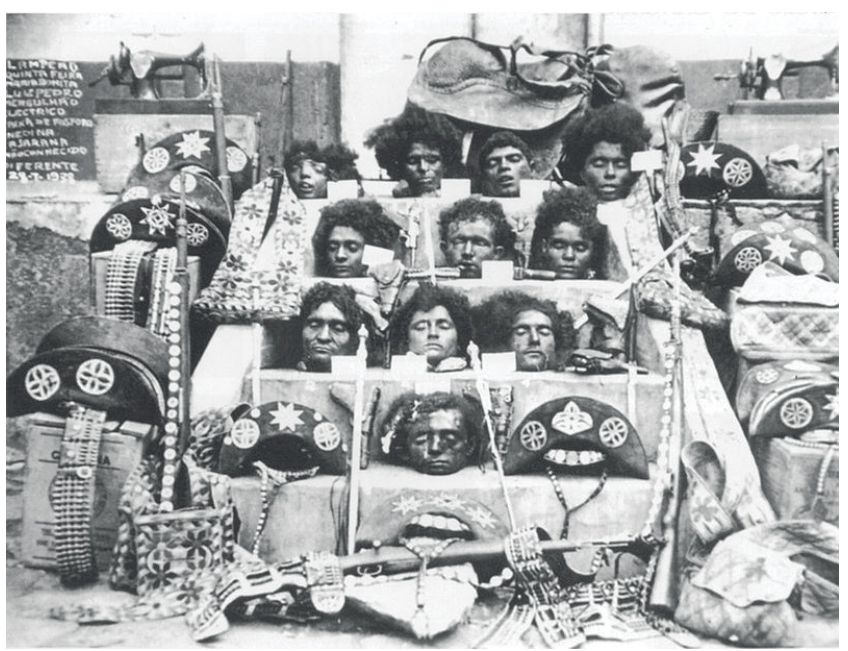

Figure 1. The heads of Lampião and 10 other bandits displayed in Piranhas, Alagoas. Lampião's head is in the first row, and that of Maria Bonita just above it. Photographer unknown CASTRO, José, in: Ciclo do Cangaço, Memórias da Bahia, vol. 4, Empresa Baiana de Jornalismo, Salvador, 2002, Public domain, https://commons. wikimedia.org/w/index. php?curid=3586224
The autopsy was conducted on July 31, 1938, during the night by Dr. José Lages Filho (1910-1997). Lages, who had graduated in 1931 at the Bahia Medical School, had been a police coroner since 1935 (Figure 2A). He was later one of the founders of the Alagoas Medical School in 1950, and became its first Professor of Forensic Medicine ${ }^{2}$.

Lampião's head, although already quite damaged from four days of inappropriate conservation in brandy and salt, was the only one that still allowed examination ${ }^{1}$. Box 1 shows the autopsy description.

At Lampião's autopsy, José Lages Filho could only find microdontia, marked ear asymmetry and an oval palatine vault as inborn traits that he considered relevant to characterize the outlaw's criminal nature according to the criteria developed and disseminated by the Italian psychiatrist, Cesare Lombroso (1835-1909).

\section{DISCUSSION}

The decapitation of criminals and political enemies, and displays of their head as a sort of trophy, was not unusual in Brazil during the $18^{\text {th }}, 19^{\text {th }}$ and early $20^{\text {th }}$ centuries, at least in the north-east region ${ }^{1,3}$. Corisco, one of Lampião's lieutenants, decapitated, while they were still alive, six family members of the police informant deemed responsible for the
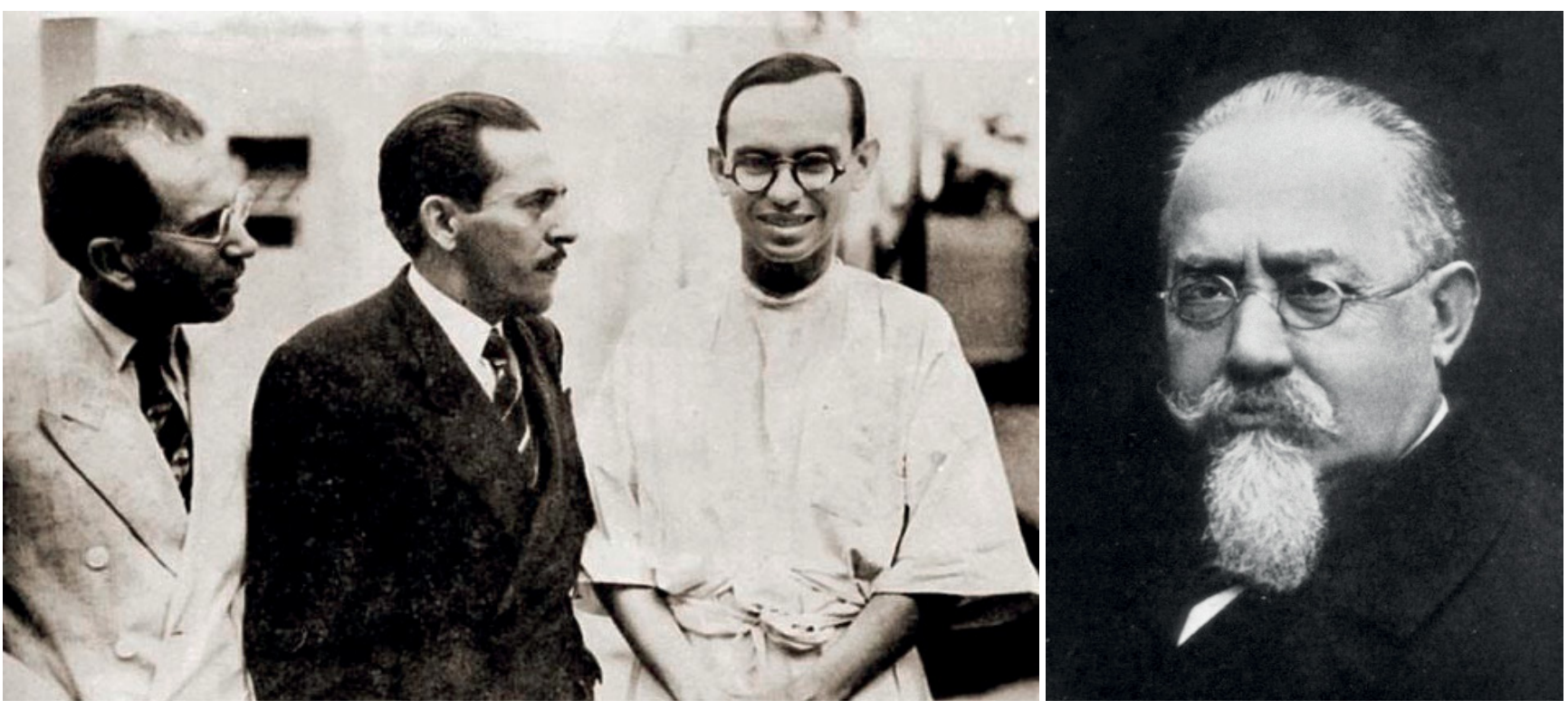

Figure 2. Doctors José Lages Filho and Cesare Lombroso. A. Dr. Lages (right side of the picture) with Dr. Ezechias da Rocha, Associate Clinical Doctor of the Santa Casa de Maceió, where the head of Lampião was examined, and Melchiades da Rocha, a journalist who documented the whole story of the criminal's death. https://i2.wp.com/www.historiadealagoas.com.br/wp-content/ uploads/2015/06/Professor-Ezechias-da-Rocha-chefe-da-Cl\%C3\%ADnica-da-Santa-Casa-jornalista-Melchiades-da-Rochae-Dr.-Lages-Filho.jpg B. The Italian positivist criminologist, Dr. Cesare Lombroso, born as Ezechia Marco Lombroso (1835-1909). Photographer unknown - reproduced in "Rassenkunde des jüdischen Volkes" by Hans F. K. Günther 1929, J.F. Lehmanns Verlag, München. Public domain, https://commons.wikimedia.org/w/index.php?curid=2770466 
Box 1. Autopsy report by Dr. José Lages Filho (authors' translation)1. The head autopsy took place only on July 31, 1938, four days after the bandit's death. Lampião's head was already in poor condition as it had been transported in a kerosene barrel full of water, brandy (cachaça) and salt, and displayed to the public in many villages during that period. The focus on anthropological classification and on features suggestive of degenerate tendencies according to Lombroso's criminal anthropometric doctrine is apparent.

"At the Medical-Legal Service of the State of Alagoas, the head of the celebrated bandit Lampião, who for 20 years was the terror of the north-eastern backlands, was admitted at 22:00 on July 31, 1938. Unfortunately, the state in which it reached the morgue does not permit a detailed and meticulous study in the light of criminal anthropometry and anatomy, since Virgulino Ferreira was struck by a firearm projectile that traversed his skull, exiting from the occipital region, hitting several bones, such as the mandibular bone at the level of its middle portion, frontal, right parietal, right temporal and base bones, which were reduced to multiple fragments. However, after careful reconstitution of the head, we can trace the anthropological profile as follows: yellow-brown skin, which classifies it as belonging to the group of "Brazilian Xanthoderms", according to the classification system of Roquette-Pinto; - fleeting forehead; - lissotric type hair, black, smooth and long, arranged in a pendant braid; - beard and moustache, with smooth, black and flaky hairs; dolichocephalic, contrasting with the other individuals of his ethnic group, brachycephalus in general. The cephalic perimeter equals 57 centimetres. The maximum antero-posterior diameter reaches 150 millimetres. Cephalic index 75 . Face of relatively small size, being impressive at first observation, the dimensions of the small mandibular bone, with the horizontal branches forming a right angle at the encounter of the corresponding ascending branches. Thus, the total face (rosto) length is $170 \mathrm{~mm}$, the total face (face) length $130 \mathrm{~mm}$, the simple face (face) length $85 \mathrm{~mm}$, the bizygomatic diameter of the maximum face transverse $160 \mathrm{~mm}$, and Broca's facial index 53.12. As for the nose, which is straight, rhomboid and with a thick apex, with the impression of glasses maintained on the dorsum, it has a maximum height of 37 millimetres. The transverse nasal index is 74 . A frank mesorrhine. Thin lips, the width of the mouth measuring $37 \mathrm{~mm}$. Ogival palatine vault. Small teeth, even fitting into the microdontia group. Asymmetric ears with a manifest inequality in the development of similar parts - Blainville's ear. The length of the right ear reaches 65 millimetres. The width of the right ear is 40 millimetres. The length of the left ear is 53 millimetres. Topinard's ear index, taking into account the dimensions of the right ear, 165. There is a visible, dark rounded pigmentation on the right masseteric region of the face, measuring three millimetres in diameter, a congenital nevus. The right eye has a leukoma, dyeing the entire cornea. In short, although some physical stigmata are present in Lampião's head, we do not find a rigorous parallel among the somatic characters of degeneration revealed by this example of a celebrated criminal. Thus, we observe as physical indices of degeneration only the anomalies of the ears, denounced by a shocking asymmetry, oval palatine vault, and microdontia. The cranial deformities, the jaw prognathism and other signs to which Lombroso lent so much in characterizing the born criminal were lacking. Nonetheless, the anatomical and anthropometric data are not worthless as they offer suggestions for appreciating the delinquent nature of the infamous north-eastern bandit. - (s.) Dr. José Lages Filho, Police Forensic Doctor".

chief's deadly ambush, and sent them to the police officer who commanded it ${ }^{1}$.

After-death phrenological analyses of outlaws were also not unheard of. For instance, Dr. Nina Rodrigues (1862-1906), Professor of Legal Medicine at the Bahia Medical Faculty and a proponent of naturalistic positivism and the Lombrosian School, performed autopsies on some outlaws ${ }^{4,5}$. He also examined the head of Antônio Conselheiro (1830-1897), the half-breed leader of the so-called War of Canudos, whose body was removed from the grave two weeks after his burial. Interestingly, Rodrigues considered the head to be normal (no degenerate anomalies having been found) ${ }^{4,5}$.

As declared by Lages, the limited autopsy was an attempt to determine whether Lampiãos head and face exhibited the characteristic traits of inborn criminals (reo nato, in the terminology of Ferri) as described by Cesare Lombroso. This influential psychiatrist (Figure 2B) was a pioneer in Forensic Psychiatry and father, along with Raffaele Garofalo (18511934) and Enrico Ferri (1856-1929), of the doctrine known as Criminal Anthropology. This was an empirically-based methodology focused on criminals. It contradicted the then-dominant metaphysical view of criminality, and classified criminals in different groups, including inborn, occasional, and passion criminals, criminal epileptics, and moral imbeciles ${ }^{6}$. Based on autopsy studies carried out in hospitals, asylums and penitentiaries, Lombroso concluded, for instance, that the occipital fossa of famous Italian criminals, such as the Calabrian robber Villela, was closer to those of superior primates than to that of humans.

According to Lombroso, aspects considered typical of the criminal character (stigmata) represented a sort of atavism regression or degeneration to a more primitive type of human 
Box 2. Characteristic physical traits of inborn criminals according to Cesare Lombroso ${ }^{6,7}$. Some of these traits indicated propensity to specific crimes including rape, murder etc. Physiological (e.g., reduced sensitivity for pain) and psychological features (vanity, childishness etc.) were also evaluated.

Unusually tall height

Small head, but large face

Bumps on head, in back of head and around ear

Wrinkles on forehead and face

Sloping forehead

Large sinus cavities or bumpy face

Large, protruding ears

Scarce beard and receding hairline

Bushy eyebrows, tending to meet across nose

Beaked nose (up or down) or flat nose

Protruding chin

High cheekbones

Mighty incisors, abnormal teeth

Thin lips (and other female traits found in rapists)

Disheveled hair

Thin neck

Long arms

Body tattoos, especially on the back and on genitals

Left-handedness

Elusive look (in thieves)

Steady and glazed look (in killers)

In criminal women, masculinity in facial traits and voice, excess body hair, warts, small or very large nipples

- that could, for instance, be caused by epilepsy, a nervous system condition that led to its degeneration ${ }^{6,7}$. These characteristics included anthropometric and phrenological/physiognomic traits such as arm and leg length, facial asymmetry, and bumps in the calvarium, but also physical marks such as tattoos and psychological characteristics that nowadays would probably be considered indicative of personality disorders (Box 2).

Lombroso's most influential work - L'uomo delinquente was published in $1876^{6}$ and was soon translated into many languages. His system - inspired by positivism - was widely adopted in Europe and other countries, including Brazil.
The Lombrosian doctrine was, however, full of prejudice against women, left-handed people, sex-workers etc. Obviously, most epileptics never commit any crime. Also, most primitive tribes (savages according to Lombroso) have low criminal rates; and normal individuals can exhibit any of the stigmata. Lombroso's theories were based on clinical observations and a large number of postmortem anthropometric measurements, but were challenged by later statistical analysis. This was used to criticize Lombroso's approach and to strengthen an opposing view of criminality that stressed the importance of societal determinants ${ }^{8}$. This new approach eventually supplanted Lombroso's view, especially after World War II.

Lombroso did not deny that exogenous factors could influence human attitudes. Eventually, he came to recognize the complex interplay between constitutional predisposition and social/precipitating factors leading to criminality, but he thought that these latter influences only acted as triggers of the endogenous factors ${ }^{7}$.

Later still, Lombroso studied mediumship and came to believe in spiritualism. His daughter Gina Ferrero suggested, however, that this latter interest could be related to the gradual appearance of dementia - "atherosclerosis".

As stated by Lages Filho, many Lombrosian physical signs of degeneration (prognathism, cranial deformities etc.) were missing in Lampião. Despite that, he stated that the anatomical and anthropometric data suggested an appreciation of the "delinquent nature" of the famous criminal. This highlights how valuable Lombroso's ideas were at the time.

A number of related doctrines coexisted or followed criminal anthropology including phrenology, social Darwinism, and eugenics. These theories strongly influenced medicine and politics during the first half of the $20^{\text {th }}$ century but eventually lost strength, especially after World War II. Despite that, the general principles behind these ideas somehow survive today. Doctors are still seeking biological traits underlying the predisposition toward misbehavior and crime, frequently adding genetic and neuroscientific arguments to the controversial field ${ }^{10}$. The jury for theories of biological determinism, however, is still out.

\section{ACKNOWLEDGMENTS}

The authors are grateful to Mrs. Solange Berard Lages Chalita for highlighting the main achievements of his father, Dr. José Lages Filho, in a friendly interview; and to Dr. Sérgio Telles Ribeiro Filho for English editing.

\section{References}

2. Canuto A. Faculdade de Medicina de Alagoas: história de luta e esperança. Maceió: UFAL; 2006.
3.

Tenório DA. A tragédia do populismo: o impeachment de Muniz

Falcão. 2nd ed. Maceió: Edufal; 2007. Raízes do conflito: a violência

política em Alagoas; p. 85-110. 
4. Mello FP. Guerreiros do Sol: violência e banditismo no Nordeste do Brasil. 5th ed. São Paulo: A Girafa; 2004.

5. Rodrigues RN. As collectividades anormaes. Rio de Janeiro: Civilização Brasileira; 1939. A loucura das multidões; p. 50-77.

6. Lombroso C. L'uomo delinquente: studiato in rapporto all'antropologia, ala medicina legale ed ala discipline carcerarie. Bologna: Il Mulino; 2011.

7. Shecaira, SS. Criminologia. 5th ed. São Paulo: Revista dos Tribunais; 2008. O nascimento da criminologia; 97-104.
8. Goring C. The English convict: a statistical study. London: HMSO; 1913 [cited2018 Apr 12]. Available from: https://archive.org/stream/ englishconvictst00goriuoft/englishconvictst00 goriuoft_djvu.txt

9. McCabe J (1920). Scientific men and spiritualism: a skeptic's analysis. Living Age. 1920 [cited 2018 May 8].

June 12;652-7. Available from: http://www.unz.com/print/LivingAge1920jun12-00652

10. Raine A. The anatomy of violence: the biological roots of crime. New York, Vintage Books; 2014. 